\title{
Electrogenic sodium-bicarbonate cotransport in human ciliary muscle cells
}

\author{
FRANK STAHL, ALBRECHT LEPPLE-WIENHUES, MARTIN KUPPINGER, \\ ERNST TAMM, AND MICHAEL WIEDERHOLT \\ Institut für Klinische Physiologie, Universitätsklinikum Steglitz, Freie Universität Berlin, \\ Hindenburgdamm 30, 1000 Berlin 45; and Institut für Anatomie, Lehrstuhl II, Universität \\ Erlangen-Nürnberg, 8520 Erlangen, Federal Republic of Germany
}

Stahl, Frank, Albrecht Lepple-Wienhues, Martin Kuppinger, Ernst Tamm, and Michael Wiederholt. Electrogenic sodium-bicarbonate cotransport in human ciliary muscle cells. Am. J. Physiol. 262 (Cell Physiol. 31): C427-C435, 1992.-We investigated membrane voltage and intracellular $\mathrm{pH}\left(\mathrm{pH}_{\mathrm{i}}\right)$ in cultured human ciliary muscle cells using a cell line $(\mathrm{H} 7 \mathrm{CM})$ and primary-cultured human ciliary muscle cells. 1) Resting potential was $58.9 \pm 1.0 \mathrm{mV}$ in $\mathrm{H} 7 \mathrm{CM}$ cells and 61.9 $\pm 1.4 \mathrm{mV}$ in primary cultures. The following data are from $\mathrm{H} 7 \mathrm{CM}$ cells, but results from primary cultures were basically similar. 2) In $\mathrm{HCO}_{3}^{-}-\mathrm{CO}_{2}$-buffered solution, removal of extracellular sodium resulted in a depolarization [change in membrane resistance $(\Delta V)=31.3 \pm 2.8 \mathrm{mV}$ ] that was less marked in the absence of $\mathrm{HCO}_{3}^{-}-\mathrm{CO}_{2}(\Delta V=0.5 \pm 2.6 \mathrm{mV})$ and reduced by $4,4^{\prime}$-diisothiocyanostilbene-2,2' -disulfonic acid (DIDS) $(\Delta V$ $=19.3 \pm 1.9 \mathrm{mV}$ ). 3) Removal of extracellular $\mathrm{HCO}_{3}^{-}-\mathrm{CO}_{2}$ led to a depolarization $(\Delta V=13.2 \pm 0.8 \mathrm{mV})$ that was abolished in the absence of extracellular sodium and inhibited by DIDS. 4) Intracellular alkalinization led to a depolarization $(\Delta V=$ $24.7 \pm 2.3 \mathrm{mV}$ ), and intracellular acidification resulted in a hyperpolarization $(\Delta V=9.4 \pm 1.1 \mathrm{mV})$ that was inhibited by DIDS and dependent on extracellular $\mathrm{HCO}_{3}^{-}-\mathrm{CO}_{2}$ and sodium. 5) $\mathrm{pH}_{\mathrm{i}}$ backregulation after an acid load occurred in both the presence and absence of extracellular bicarbonate but not in the absence of extracellular sodium. Our data are consistent with an electrogenic $\mathrm{Na}^{+}-\mathrm{HCO}_{3}^{-}$cotransport in human ciliary muscle cells, which is activated by intracellular acidification.

membrane potential; intracellular $\mathrm{pH}$; cell culture

THE HUMAN CILIARY MUSCLE is involved in both the accommodation and the regulation of aqueous humor outflow facility. In contrast to our knowledge about many other smooth muscles, not much is available on cellular mechanisms involved in the regulation of ciliary muscle contractility. Earlier morphological studies pointed out that the ciliary muscle seems to differ from other smooth muscles, slightly resembling a striated muscle in some respects $(11,29)$. Contractility in smooth muscle is closely related to membrane properties. We therefore characterized some properties of the plasma membrane of ciliary muscle cells. Our model to investigate ciliary muscle cell properties was primary-cultured human ciliary muscle cells (27) and the H7CM cell line (18). This cell line is known to be of muscular origin and has already been used for ciliary muscle investigations, including studies on membrane transport properties $(18,19,26)$. In this paper, special attention was directed toward testing for the presence of sodium-dependent bicarbonate transport mechanisms, namely electrogenic sodium bicarbonate cotransport, which transports one sodium ion together with two or more bicarbonate ions. This transport system has been described previously in a great number of different epithelial $(2,7,12,20,22,25,31,32)$ and glial cells (8) but has not yet been demonstrated in the plasma membrane of cells of muscular origin. The $\mathrm{Na}^{+}-\mathrm{HCO}_{3}^{-}$cotransport is supposed to contribute to the maintenance of the membrane potential (15) and to play a role in transepithelial bicarbonate transport $(25,32)$ as well as in the regulation of intracellular $\mathrm{pH}\left(\mathrm{pH}_{\mathrm{i}}\right)(17$, $22,28,30,31$ ). The $\mathrm{Na}^{+}-\mathrm{HCO}_{3}^{-}$cotransport in bicarbonate-reabsorbing epithelia is considered to be located in the basolateral membrane, mediating basolateral bicarbonate fluxes $(2,9,22,25)$. In these cells, bicarbonate is transported across the cell membrane from inside to outside under steady-state conditions. The stoichiometry is supposed to be $3: 1$ rather than $2: 1(25,32)$. In contrast, in cultured renal BSC1 cells, this transporter has been shown to carry a net negative charge inside the cell, contributing to some extent to the resting membrane potential (15). In the present study, we demonstrate membrane properties consistent with such a transport system in human ciliary muscle cells using conventional intracellular microelectrodes to determine the membrane potential and a $\mathrm{pH}$-sensitive dye to estimate the $\mathrm{pH}_{\mathrm{i}}$.

\section{METHODS}

Cell culture. Cells of an established cell line (H7CM) derived from the ciliary muscle of a 1-day-old human infant as previously described (18) were cultured in cell-culture flasks (80 $\mathrm{cm}^{2}$ ). These cells have been characterized to be of smooth muscle origin by ultrastructural analysis and immunostaining for smooth muscle specific $\alpha$-isoactin (18). When cells had reached confluency, they were subcultured at a split ratio of 1:4 using $\mathrm{Ca}^{2+}$-free and $\mathrm{Mg}^{2+}$-free phosphate-buffered saline (PBS) containing $0.05 \%$ trypsin and $0.02 \%$ EDTA. Finally, the cells were grown to confluent monolayers in Petri dishes (for intracellular voltage recordings) and on cover slips, which were placed in Leighton tubes (for measurement of $\mathrm{pH}_{\mathrm{i}}$ ). Cells were maintained at $37^{\circ} \mathrm{C}$ in an atmosphere containing $95 \%$ air-5\% $\mathrm{CO}_{2}$. The culture medium was medium 199 supplemented with $10 \%$ fetal calf serum and $100 \mathrm{U} / \mathrm{l}$ penicillin and $100 \mu \mathrm{g} / \mathrm{ml}$ streptomycin. Medium exchange was performed twice a week. Under these conditions, H7CM cells reached confluency within 7 days and were used for experiments $2-3 \mathrm{wk}$ after subculture. The H7CM cells in this study were from passages 6 to 15 . Light-microscopic morphological controls revealed no change in the appearence of the cells in all passages used.

Primary culture of human ciliary muscle cells. The primary ciliary muscle culture was established from the eyes of a 16year-old human donor. After dissection of the eye, strips from the outer parts of the muscle (longitudinal portion) were cut free and placed in medium 199. Histological control sections confirmed that the explants did not include ciliary epithelium, trabecular meshwork, or tissue from the stroma of the ciliary processes or the choroid. Ciliary muscle cells were isolated by digestion of the explant with collagenase and seeded in Petri 
dishes (for details see Ref. 27). At confluency, the cells grew in a hill-and-valley pattern typical for smooth muscle cells in culture. The purity of the ciliary muscle culture was further controlled by a detailed immunocytochemical and ultrastructural characterization (27). Light-microscopic controls of the subcultures used for membrane voltage measurements revealed no change in the appearence of the cells up to the eighth passage. Confluent cells were subcultured using the method described for H7CM cells. Membrane voltage measurements were performed with cells from the passages 6-8.

Membrane voltage recordings. The experimental setup has previously been described in detail (13). In short, a Petri dish with attached cells was inserted in a temperature-controlled chamber $\left(37^{\circ} \mathrm{C}\right)$. A flow chamber was clamped on the bottom of the Petri dish, isolating a small channel (width, $1.5 \mathrm{~mm}$; length, $30 \mathrm{~mm}$ ). This channel could be rapidly superfused by up to eight different test solutions with a $90 \%$ fluid exchange occurring within $3 \mathrm{~s}$ at a perfusion rate of $30 \mathrm{ml} / \mathrm{h}$. Solution exchanges were performed using electromagnetic valves (Lucifer type 133 A 54, Geneva, Switzerland). Microelectrodes were drawn from filament borosilicate glass capillaries $(1.0 \mathrm{~mm} O D$, $0.58 \mathrm{~mm}$ ID; Hilgenberg, Malsfeld, FRG) using a DMZ-Universal puller (Zeitz Instrumente, Augsburg, FRG). Electrodes were filled with $0.5 \mathrm{M} \mathrm{KCl}$ solution (resistance in Ringer solution 50-120 M $\Omega$ ). The cells on the bottom of the flow channel were impaled by a microstepping device (Heidelberg Nanostepper, Science Trading, Frankfurt, FRG) that advances the electrode until a stable membrane voltage recording was obtained. The microelectrode was connected to an electrometer amplifier (WPI model M4-A, World Precision Instruments, Hamden, $\mathrm{CT}$ ), and the time course of the membrane voltage was continuously registered on a chart recorder.

Measurement of $\mathrm{pH}_{i}$. To measure $\mathrm{pH}_{\mathrm{i}}$, we used the $\mathrm{pH}$ sensitive dye 5- and 6-carboxy- $4^{\prime}, 5^{\prime}$-dimethylfluorescein (CDMF). A detailed description of the experimental setup has already been reported (14). Briefly, the absorbance of CDMF is $\mathrm{pH}$ sensitive at $509 \mathrm{~nm}$ but nearly $\mathrm{pH}$ insensitive at $470 \mathrm{~nm}$. Thus $\mathrm{pH}$ can be estimated from the ratio of absorbance at 509 and $470 \mathrm{~nm}$. For $\mathrm{pH}_{\mathrm{i}}$ experiments, a cover slip covered with cells was cut in half. One half (indicator cells) was incubated for $30 \mathrm{~min}$ with CDMF-diacetate $(100 \mu \mathrm{M})$. The second half of the cover slip (control cells) was incubated in an identical solution without dye. Indicator and control cells were placed in a cuvette where they could be superfused with different test solutions. These test solutions were temperature regulated at $37^{\circ} \mathrm{C}$ and appropriately aerated with $5 \% \quad \mathrm{CO}_{2}-95 \%$ air. The cuvette contains $\sim 3 \mathrm{ml}$ solution, which can be exchanged within 3-5 s. Transmittance was monitored continuously using a dualbeam dual-wavelength photometer. Data are presented as the ratio of transmittance at 509 and $470 \mathrm{~nm}$, corrected for the non- $\mathrm{pH}_{\mathrm{i}}$ related absorbance variations in the control cells. At the end of the recording, each experiment was calibrated using the nigericin method (3).

Solutions and source of chemicals. Standard bicarbonate solution contained the following ionic concentrations (in $\mathrm{mM}$ ): $123 \mathrm{NaCl}, 28 \mathrm{NaHCO}_{3}, 4 \mathrm{KCl}, 1.7 \mathrm{CaCl}_{2}, 1 \mathrm{KH}_{2} \mathrm{PO}_{4}, 0.9 \mathrm{MgSO}_{4}$, and 5 glucose. In the high-bicarbonate solution, $18 \mathrm{mmol} \mathrm{NaCl}$ was replaced by $\mathrm{NaHCO}_{3}$, leading to a final concentration of $46 \mathrm{mM} \mathrm{HCO}_{3}^{-}$. Bicarbonate-containing solutions were aerated with different concentrations of $\mathrm{CO}_{2}$ to yield a $\mathrm{pH}$ of 7.4. Bicarbonate-free solutions were buffered with $10 \mathrm{mM} \mathrm{N-2-}$ hydroxyethylpiperazine- $N^{\prime}$-2-ethanesulfonic acid (HEPES) to $\mathrm{pH}$ 7.4. In solutions containing a lower sodium concentration, sodium was replaced by equimolar amounts of $N$-methyl-Dglucamine (NMDG). In solutions designed to change $\mathrm{pH}_{\mathrm{i}}$ by nonionic diffusion, $20 \mathrm{mmol} \mathrm{NaCl}$ were replaced by $20 \mathrm{mmol}$ $\mathrm{NH}_{4} \mathrm{Cl}$. Cell culture media and supplements were purchased from Biochrom KG, Berlin, FRG. Tissue culture flasks and dishes were from Nunc A/S, Roskilde, Denmark. Leighton tubes were supplied by Costar, Cambridge, MA. CDMF-diacetate was purchased from Molecular Probes, Eugene, OR. Nigericin and 4,4'-diisothiocyanostilbene-2,2' -disulfonic acid (DIDS) were obtained from Sigma Chemical, St. Louis, MO.

\section{RESULTS}

Membrane voltages under steady-state conditions. Successful impalement of a cell superfused by standard bicarbonate solution resulted in a steep rapid deflection of the recorded voltage followed by a further increase over several minutes until a stable value was reached. Experiments were continued only when the electrode resistance was the same before and after impalement and when the recorded voltage had been stable for at least 3 min. Under these conditions, the average resting potential obtained from stable impalements of H7CM cells was $-58.9 \pm 1.0 \mathrm{mV}(n=116)$. The values coincide with our previously reported findings (18). We were also able to obtain stable recordings in primary cultures of human ciliary muscle cells. Mean values of $61.9 \pm 1.4 \mathrm{mV}(n=$ 19) were basically in the same range as those obtained in the cell line.

Removal of extracellular bicarbonate. Rapid change of the extracellular fluid from high-bicarbonate solution (46 $\left.\mathrm{mM} \mathrm{HCO}_{3}^{-}-9 \% \quad \mathrm{CO}_{2}\right)$ to bicarbonate-free solution at a constant extracellular $\mathrm{pH}\left(\mathrm{pH}_{\mathrm{o}}\right)$ resulted in rapid membrane depolarization (see Fig. $1 A$ and Table 1). When $\mathrm{HCO}_{3}^{-}$was withdrawn for longer periods, the depolarization reached a plateau after 3-4 min (data not shown). The depolarizing effect induced by removing extracellular bicarbonate could be inhibited by $\operatorname{DIDS}\left(10^{-3} \mathrm{M}\right)$, a well-known blocker of various anion transporters. This inhibiting effect increased with the time of DIDS application (3 and $7 \mathrm{~min}$ ) and was nearly complete after 11 min (Fig. 1A). The progressive effect of DIDS can be explained by increased covalent binding of DIDS during prolonged exposure of the cells. Furthermore, DIDS is considered to act from the internal side of the plasma membrane and the delay of the DIDS effect may be due to slow diffusion of sufficient amounts of DIDS through the plasma membrane. Figure $1 B$ summarizes 11 experiments similar to those shown in Fig. $1 A$. An additional observation was a depolarizing effect of DIDS $\left(10^{-3} \mathrm{M}\right)$ per se, as shown in Figs. 1 and $6(\Delta V$ by some $3-10 \mathrm{mV})$. This might indicate that DIDS interferes with a transporter that carries a net negative charge across the cell membrane.

To exclude an indirect mediation of the effects in Fig. $1, A$ and $B$, by rapid intracellular $\mathrm{pH}$ alterations during simultaneous $\mathrm{HCO}_{3}^{-}-\mathrm{CO}_{2}$ withdrawal (removal of $\mathrm{HCO}_{3}^{-}$$\mathrm{CO}_{2}$ would lead to an initial rapid alkalinization due to decreased $\mathrm{PCO}_{2}$ ), we measured $\mathrm{pH}_{\mathrm{i}}$ using the experimental protocol described in Fig. $1 A$. Repeated withdrawal of $\mathrm{HCO}_{3}^{-}-\mathrm{CO}_{2}$ for $2 \mathrm{~min}$ always led to a rapid intracellular alkalinization, which was not significantly influenced by DIDS $\left(10^{-3} \mathrm{M}\right)$. In addition, we also observed a marked depolarization when extracellular bicarbonate was withdrawn at a constant $\mathrm{PCO}_{2}$ (data not shown).

If the depolarization observed after removal of external bicarbonate is due to an electrogenic $\mathrm{Na}^{+}-\mathrm{HCO}_{3}^{-}$cotrans- 


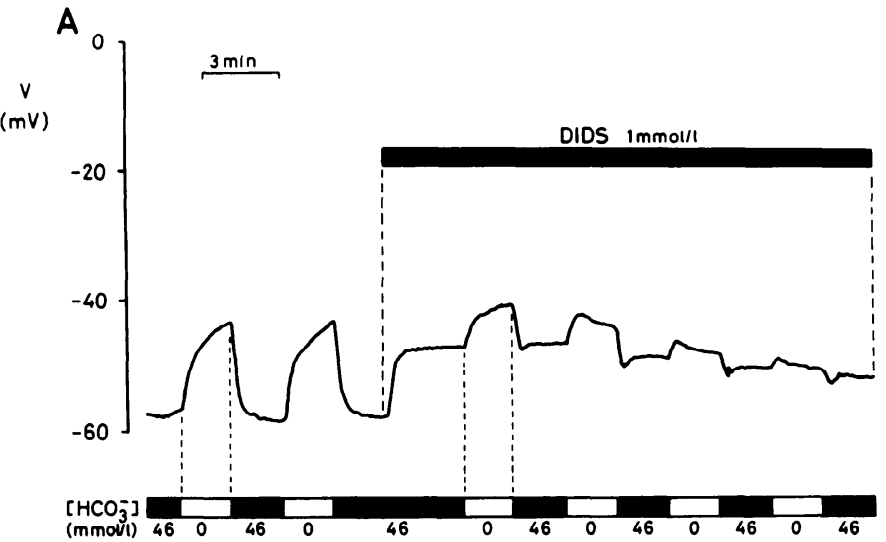

$B \quad \stackrel{\Delta V}{(m V)}$

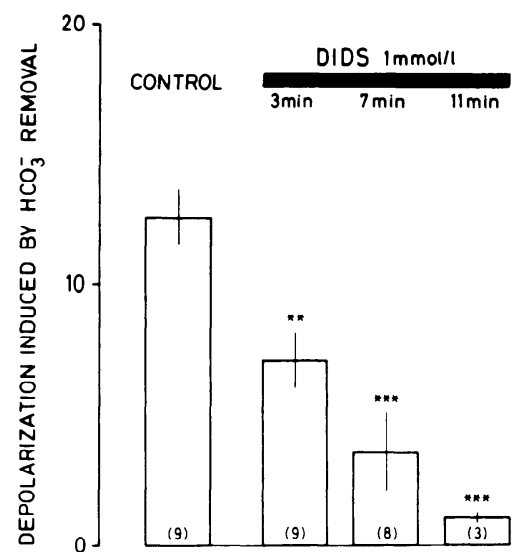

Fig. 1. A: one representative experiment in which depolarization is achieved by changing extracellular solution from $46 \mathrm{mM} \mathrm{HCO}_{3}^{-}$and $9 \% \mathrm{CO}_{2}$ to unaerated and nominally $\mathrm{HCO}_{3}^{-}$-free solution at a constant extracellular $\mathrm{pH}$ (7.4). Depolarization is inhibited in presence of DIDS $(1 \mathrm{mM}) . B$ : experiments like the one shown in $A$ are summarized. DIDS significantly inhibited depolarization induced by $\mathrm{HCO}_{3}^{-}$removal ${ }^{* *} P$ $<0.01 ;{ }^{* * *} P<0.001$, paired Student's $t$ test). The inhibiting effect of DIDS increased with its time of application.

Table 1. Depolarization $(\Delta V)$ induced by removal of $\mathrm{Na}^{+}$or $\mathrm{HCO}_{3}^{-}-\mathrm{CO}_{2}$ for $2 \mathrm{~min}$

\begin{tabular}{|c|c|c|c|c|}
\hline & \multicolumn{2}{|c|}{$0 \mathrm{Na}^{+}$} & \multicolumn{2}{|c|}{$0 \mathrm{HCO}_{3}^{-}$} \\
\hline & 0 DIDS & + DIDS & 0 DIDS & + DIDS \\
\hline Cell line (H7CM), $\mathrm{mV}$ & $\begin{array}{c}31.3 \pm 2.8 \\
(15)\end{array}$ & $\begin{array}{c}19.3 \pm 1.9 \\
(15)^{*}\end{array}$ & $\begin{array}{c}12.6 \pm 1.0 \\
(9)\end{array}$ & $\begin{array}{c}7.0 \pm 1.3 \\
(9) \dagger\end{array}$ \\
\hline Primary culture, $\mathrm{mV}$ & $\begin{array}{c}31.3 \pm 4.3 \\
\text { (3) }\end{array}$ & $\begin{array}{c}24.6 \pm 3.2 \\
(3) \neq\end{array}$ & $\begin{array}{c}12.7 \pm 2.4 \\
(9)\end{array}$ & \\
\hline
\end{tabular}

Values are given as means \pm SE. $* P<0.001, \dagger P<0.01, \ddagger P<0.05$, paired Student's $t$ test. No. of observations given in parentheses.

porter, removal of extracellular sodium should result in a bicarbonate-dependent and DIDS-sensitive membrane depolarization. An additional prediction is the reduction of the described effect of bicarbonate withdrawal under sodium-free conditions. To test these hypotheses, we first performed experiments removing extracellular sodium in the presence of $\mathrm{HCO}_{3}^{-}-\mathrm{CO}_{2}$.

Sodium removal in the presence of bicarbonate. Removal of sodium for $2 \mathrm{~min}$ in the presence of $\mathrm{HCO}_{3}^{-} / \mathrm{CO}_{2}$ caused a marked depolarization $(\Delta V=31.3 \pm 2.8 \mathrm{mV} ; n$ $=15$ ), and its readdition led to complete repolarization
(Fig. 2A). When sodium was removed for periods of more than $2 \mathrm{~min}$, the depolarization reached a plateau after 45 min. In some experiments, we observed an initial hyperpolarization when extracellular sodium was removed. Figure $2 A$ also demonstrates that the magnitude of the depolarization depends on the residual extracellular sodium concentration. Decreasing the extracellular sodium concentration from 150 to $40 \mathrm{mM}$, from 150 to $20 \mathrm{mM}$, and from 150 to $0 \mathrm{mM}$ resulted in an increasing membrane depolarization. Figure $2 B$ summarizes $11 \mathrm{ex}-$ periments like those shown in Fig. $2 A$.

The depolarization induced by removal of extracellular sodium was reduced from $31.3 \pm 2.8 \mathrm{mV}(n=15)$ in the absence of DIDS to $19.3 \pm 1.9 \mathrm{mV}(n=15)(P<0.001)$ in its presence, as shown in Fig. $2 A$. The inhibiting effect of DIDS was almost completely reversible when DIDS was applied for short periods (2 min in Fig. $2 A$ ). In contrast to the depolarization caused by removal of extracellular bicarbonate, that induced by removal of extracellular sodium could not be completely abolished, even if $1 \mathrm{mM}$ DIDS was present up to $20 \mathrm{~min}$ (data not shown).

Sodium removal in the absence of bicarbonate. Quanti-
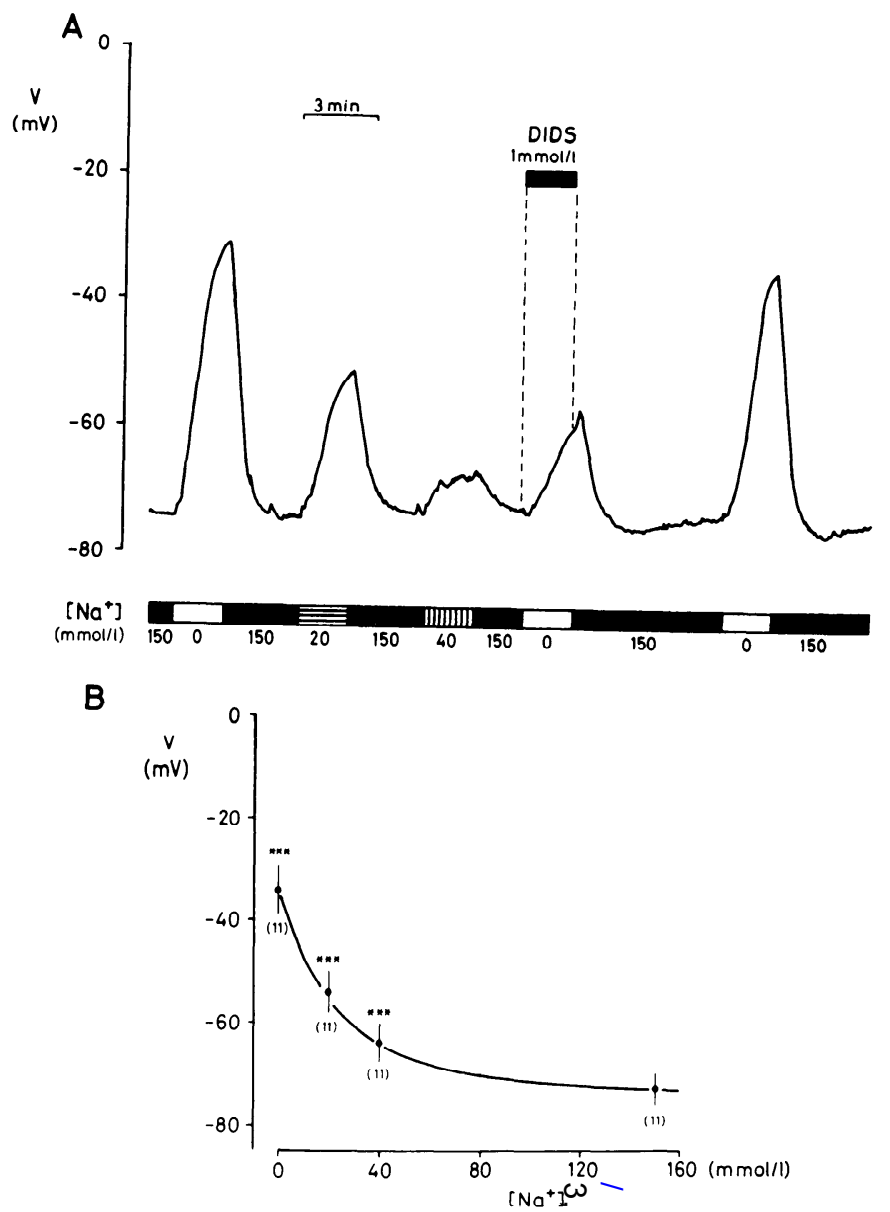

Fig. 2. A: depolarization induced by removåof extracellular sodium decreased with increasing residual sodium $\overrightarrow{N O}$ extracellular solution. Depolarization was reversibly inhibited by $1 \mathrm{mM}$ DIDS. $B$ : this summarizes 11 experiments like one shown in left of $A$. Membrane potential 2 min after reducing extracellular sodium from $151 \mathrm{mM}$ to lower concentrations is plotted against extracellular sodium concentration (*** $P<0.001$, paired Student's $t$ test). 
tative analysis of 19 experiments, in which we performed sodium removal for $2 \mathrm{~min}$, first in the presence and then in the absence of $\mathrm{HCO}_{3}^{-}-\mathrm{CO}_{2}$, yielded a depolarization of $34.5 \pm 2.9 \mathrm{mV}(n=19)$ and $0.5 \pm 2.6 \mathrm{mV}(n=19)$, respectively $(P<0.001)$. Thus the depolarization is dependent on the presence of bicarbonate. However, the voltage responses on removal of extracellular sodium in the absence of $\mathrm{HCO}_{3}^{-}-\mathrm{CO}_{2}$ showed a greater variability than those observed in its presence. In some experiments, we observed a depolarization upon removal of extracellular sodium even in its absence (Fig. 3, right). This depolarization was markedly smaller than that observed in the presence of $\mathrm{HCO}_{3}^{-}-\mathrm{CO}_{2}$ (Fig. 3, left). In other experiments (example shown in Fig. 4), there was no depolarization but only a hyperpolarization when sodium was removed in the absence of $\mathrm{HCO}_{3}^{-}-\mathrm{CO}_{2}$ and a rapid depolarization when it was readded. The depolarization sometimes led to a superimposed action potential when the action potential threshhold was reached. The reason for variability of the responses to sodium removal in the absence of $\mathrm{CO}_{2}-\mathrm{HCO}_{3}^{-}$is not clear. One explanation might be that the hyperpolarizing effect induced by sodium removal is uncovered in the absence of $\mathrm{CO}_{2}$ $\mathrm{HCO}_{3}^{-}$. This may contribute more or less to the voltage changes induced by sodium removal, thus leading to the variable responses.

Changes in $\mathrm{pH}_{i}$ induced by removal of extracellular sodium. To test whether changes in $\mathrm{pH}_{\mathrm{i}}$ can explain voltage changes induced by sodium removal, we measured $\mathrm{pH}_{\mathrm{i}}$ during removal of extracellular sodium in control conditions (presence $\mathrm{CO}_{2}-\mathrm{HCO}_{3}^{-}$), in the absence of $\mathrm{CO}_{2}-\mathrm{HCO}_{3}^{-}$and in the presence of DIDS. Removal of extracellular sodium resulted in an intracellular acidification. The grade of acidification was not significantly different in the various conditions as summarized in Table 2. Thus the acidification seems to be primarily mediated via a bicarbonate-independent and DIDS-insensitive mechanism, which is most probably $\mathrm{Na}^{+}-\mathrm{H}^{+}$ exchange. Because the changes in $\mathrm{pH}_{\mathrm{i}}$ induced by sodium removal are not significantly dependent on $\mathrm{CO}_{2}-\mathrm{HCO}_{3}^{-}$ and not significantly influenced by DIDS, the corresponding voltage changes cannot be attributed to different changes in $\mathrm{pH}_{\mathrm{i}}$.

Voltage variations with $\mathrm{pH}_{i}$. This series of experiments was performed to demonstrate a possible activation of the electrogenic $\mathrm{Na}^{+}-\mathrm{HCO}_{3}^{-}$transporter by cytoplasmic acidification. We therefore acidified the cells using the ammonium chloride prepulse technique (3). In short, extracellular addition of $\mathrm{NH}_{4} \mathrm{Cl}$ leads to an intracellular alkalinization by nonionic diffusion of $\mathrm{NH}_{3}$ across the plasma membrane and subsequent association of $\mathrm{H}^{+}$. Conversely, an overshoot acidification is observed when $\mathrm{NH}_{4} \mathrm{Cl}$ is removed after sufficient amounts of $\mathrm{NH}_{4}^{+}-\mathrm{NH}_{3}$ have accumulated in the cell due to influx of $\mathrm{NH}_{4}^{+}$during the plateau phase. This typical $\mathrm{pH}_{\mathrm{i}}$ behavior is shown in Fig. 5, top. Intracellular alkalinization induced by addition of $\mathrm{NH}_{4} \mathrm{Cl}$ resulted in an initial rapid $(\Delta V=7.6 \pm$ $1.2 \mathrm{mV}, n=9$ ) and a subsequent slow depolarization of the membrane voltage $(\Delta V=24.7 \pm 2.3 \mathrm{mV}, n=9,3$ $\min \mathrm{NH}_{4} \mathrm{Cl}$ ). Depolarization initially corresponded to the rapid intracellular alkalinization and then took a markedly slower course. When $\mathrm{NH}_{4} \mathrm{Cl}$ was removed, the membrane voltage rapidly repolarized leading to a significant $(P<0.001)$ hyperpolarization compared with the resting potential prior to extracellular $\mathrm{NH}_{4} \mathrm{Cl}$ application $(\Delta V=$ $9.4 \pm 1.1 \mathrm{mV}, n=5$ ). The time course of this hyperpolarizing effect was nearly identical to that of the acidification observed in our $\mathrm{pH}_{\mathrm{i}}$ experiments (Fig. 5). If the hyperpolarizing effect of intracellular acidification is due to an activation of the $\mathrm{Na}^{+}-\mathrm{HCO}_{3}^{-}$cotransporter, it should depend on the presence of bicarbonate and extracellular sodium. Furthermore, the effect should be DIDS sensitive. Figure 5 (which combines six representative experiments) shows the bicarbonate and the sodium dependence of the hyperpolarizing effect. The corresponding $\mathrm{pH}_{\mathrm{i}}$ variations are shown in the top part of Fig. 5 . The hyperpolarization only occurred in the presence of both bicarbonate and extracellular sodium (Fig. 5A). Withdrawal of bicarbonate (Fig. $5 B$ ) or extracellular sodium (Fig. $5 C$ ) during the acidification inhibited the hyperpolarization usually observed. Another interesting finding was that action potentials could be induced by intracellular alkalinization, as shown in the bottom of Fig. $5 B$. In Fig. 6, we demonstrate the bicarbonate dependence and DIDS sensitivity of the hyperpolarization. There are residual changes in the membrane voltage in the absence of $\mathrm{CO}_{2}-\mathrm{HCO}_{3}^{-}$and in the presence of DIDS. These residual changes may be due to mechanisms different from sodium bicarbonate cotransport or the con-

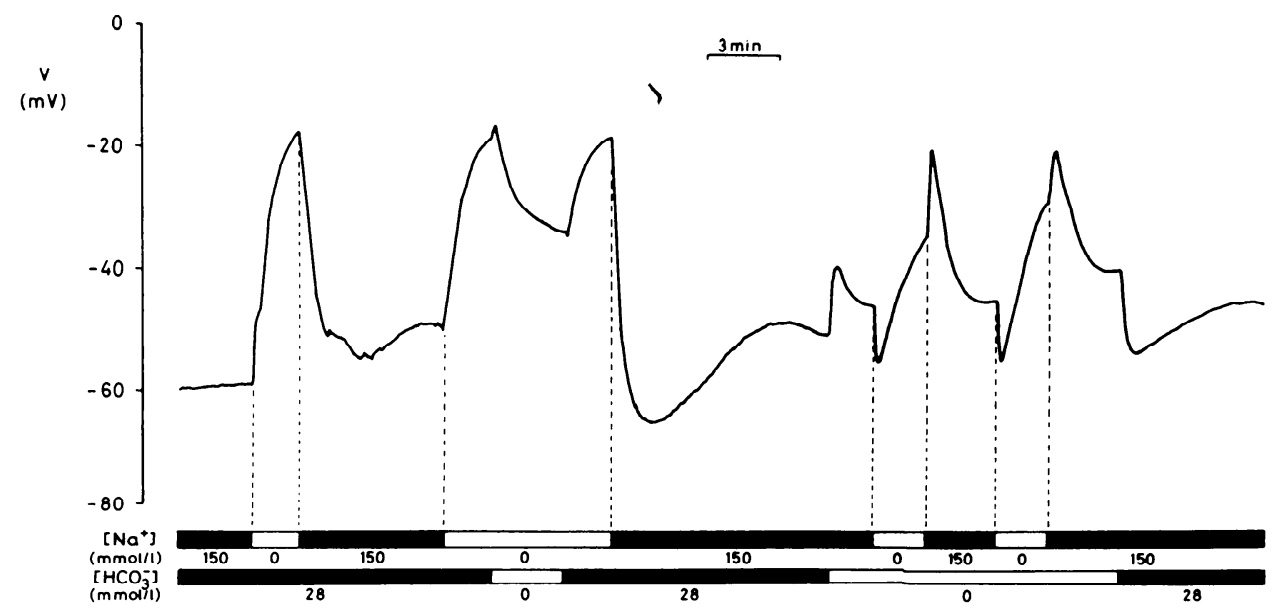

Fig. 3. This recording shows that removal of extracellular sodium caused a less marked depolarization in absence (right of recording) than in presence of $\mathrm{HCO}_{3}^{-}-\mathrm{CO}_{2}$ (left of recording). Furthermore, a repolarization, but no additional depolarization, is observed when $\mathrm{HCO}_{3}^{-}$$\mathrm{CO}_{2}$ is removed in absence of extracellular sodium. 


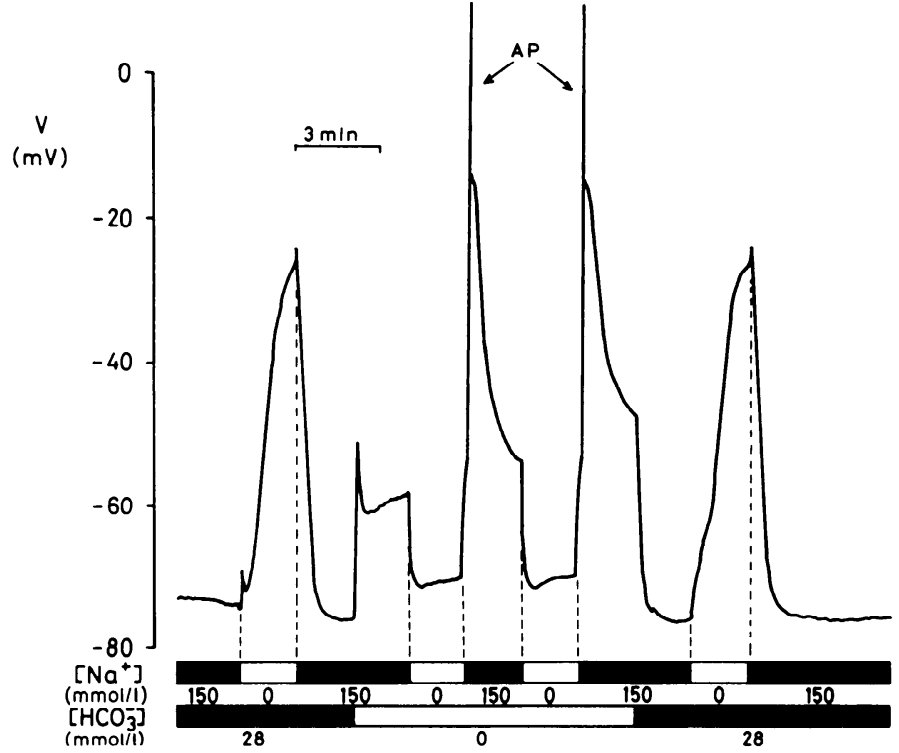

Fig. 4. In some experiments, depolarizing effect of sodium removal was completely abolished in absence of $\mathrm{HCO}_{3}^{-}-\mathrm{CO}_{2}$, and only a hyperpolarization was observed when extracellular sodium was removed. Readdition of sodium to extracellular solution resulted in rapid depolarization and induced action potentials, as indicated by arrows.

Table 2. Changes in $p H_{i}$ induced by removal of external $\mathrm{Na}^{+}$for $2 \min \left(\Delta p H_{i}\right)$

\begin{tabular}{cccc}
\hline & $0 \mathrm{Na}^{+}-28 \mathrm{HCO}_{3}^{-}$ & $0 \mathrm{Na}^{+}-0 \mathrm{HCO}_{3}^{-}$ & $0 \mathrm{Na}^{+}-28 \mathrm{HCO}_{3}^{-}-\mathrm{DIDS}$ \\
\hline $\mathrm{JpH} \mathrm{i}$ & $\begin{array}{c}0.26 \pm 0.05 \\
(5)\end{array}$ & $0.21 \pm 0.03$ & $\begin{array}{c}0.29 \pm 0.01 \\
(4)\end{array}$ \\
& $(3)$
\end{tabular}

Values are given as means $\pm \mathrm{SE}$ and not significantly different from each other. No. of observations given in parentheses.

sequence of incomplete inactivation of this transport in the absence of $\mathrm{CO}_{2}-\mathrm{HCO}_{3}^{-}$or in the presence of DIDS. However, we did not observe a hyperpolarization beyond $-60 \mathrm{mV}$ like that seen in the presence of $\mathrm{CO}_{2}-\mathrm{HCO}_{3}^{-}$ (Fig. 6, left).

Removal of external $\mathrm{Na}^{+}$or $\mathrm{HCO}_{3}^{-}$in primary-cultured ciliary muscle cells. All experiments demonstrated in Figs. 1-6 have dealt with cultured human ciliary muscle cells of the H7CM cell line. We performed some additional experiments using ciliary muscle cells of primary-cultured human ciliary muscle. These cells are morphologically characterized as ciliary muscle cells (27). However, further functional characterization needs to be done. In this study, we restrict ourselves to demonstrate the excitability and only two of the six properties (see DISCUSSION) predicted from electrogenic $\mathrm{Na}^{+}-\mathrm{HCO}_{3}^{-}$cotransport. Addition of $10 \mathrm{mM} \mathrm{Ba}{ }^{2+}$, an inorganic blocker of potassium channels, resulted in a rapid depolarization with superimposed overshooting action potentials, as shown in Fig. $7 \mathrm{~A}$. We have demonstrated similar $\mathrm{Ba}^{2+}$ induced action potentials in H7CM cells (18).

Changing the extracellular environment from a highto a low-bicarbonate solution for $2 \mathrm{~min}$ resulted in a membrane depolarization $(\Delta V=12.7 \pm 2.4 \mathrm{mV}, n=9)$ (Fig. $7 B$ and Table 1) similar to that observed in $\mathrm{H} 7 \mathrm{CM}$ cells. Furthermore, removal of extracellular sodium for 2 min also led to a marked depolarization $(\Delta V=31.3 \pm$ $4.3 \mathrm{mV}, n=3$ ) (Fig. $7 C$ and Table 1). This depolarization was significantly reduced to $24.6 \pm 3.2 \mathrm{mV}$ in the pres-

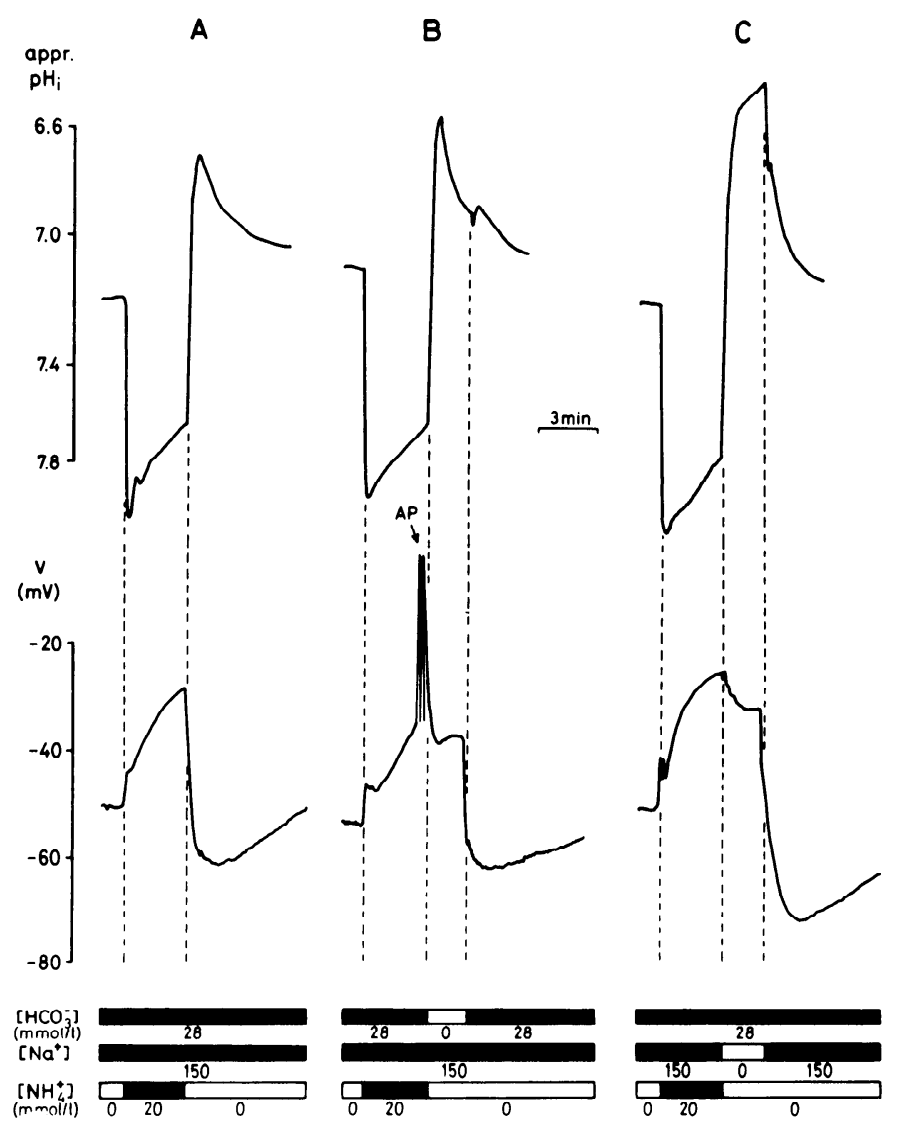

Fig. 5. This summarizes results of 6 single experiments. Recordings of membrane voltage (bottom) and corresponding $\mathrm{pH}_{\mathrm{i}}$ changes $($ top $)$ are shown. $A$ : result of applying $\mathrm{NH}_{4} \mathrm{Cl}$ in presence of $\mathrm{HCO}_{3}^{-}-\mathrm{CO}_{2} . \mathrm{NH}_{4} \mathrm{Cl}$ and $\mathrm{HCO}_{3}^{-}-\mathrm{CO}_{2}$ are removed simultaneously in $\mathrm{B}$ and $\mathrm{NH}_{4} \mathrm{Cl}$ and sodium in $C$. Hyperpolarization observed when $\mathrm{H} 7 \mathrm{CM}$ cells were acid loaded was dependent on both $\mathrm{HCO}_{3}^{-}-\mathrm{CO}_{2}$ and extracellular sodium. In some experiments, action potentials (indicated by arrow) were induced by intracellular alkalinization.

ence of DIDS (Table 1). In summary, the data obtained from primary cultured human ciliary muscle cells are in principle similar to those obtained from H7CM cells.

\section{DISCUSSION}

$\mathrm{Na}^{+}-\mathrm{HCO}_{3}^{-}$cotransport. In this paper, we report that cultured human ciliary muscle cells exhibit membrane properties fulfilling the six key predictions $(2,12)$ of an electrogenic $\mathrm{Na}^{+}\left(\mathrm{HCO}_{3}^{-}\right)_{\mathrm{n}}$ cotransport system $(n>1)$ carrying a net negative charge: 1) depolarization on removal of extracellular $\mathrm{HCO}_{3}^{-}$;2) depolarization on removal of extracellular $\mathrm{Na}^{+} ; 3$ and 4) the response to sodium is dependent on the presence of bicarbonate and vice versa; and 5 and 6 ) both responses are partially inhibitable by the disulfonic stilbene DIDS.

Stilbene derivates like DIDS or 4 -acetamido- ${ }^{\prime}$-isothiocyanostilbene-2,2' -disulfonic acid have often been used to identify the role of sodium bicarbonate cotransport in transmembrane and transepithelial ion transport $(12,14)$. The concentrations used are generally between $0.1 \mathrm{mM}$ and $1 \mathrm{mM}$ DIDS. However, these drugs are not specific inhibitors of sodium bicarbonate cotransport because other anion transporters like sodium-dependent or sodium-independent chloride bicarbonate exchange are also inhibited by DIDS. Thus an effect of DIDS alone 


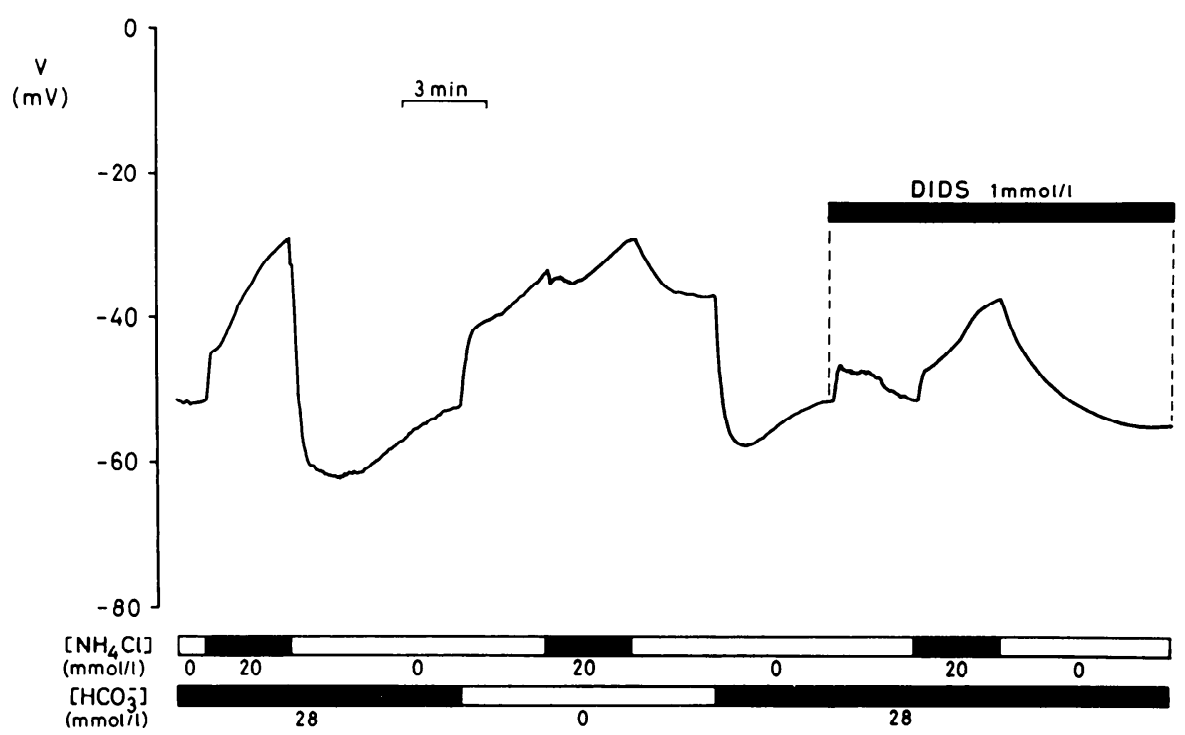

Fig. 6. Variations in membrane voltage induced by intracellular alkalinization and acidification $\left(\mathrm{NH}_{4} \mathrm{Cl}\right.$ prepulse technique) are shown. $\mathrm{NH}_{4} \mathrm{Cl}$ prepulses were performed in presence (left) and absence (middle) of $\mathrm{HCO}_{3}^{-}-\mathrm{CO}_{2}$ as well as in presence of $1 \mathrm{mM}$ DIDS (right). Hyperpolarization induced by intracellular acidification was not observed in absence of $\mathrm{HCO}_{3}^{-}-\mathrm{CO}_{2}$ or in presence of $1 \mathrm{mM}$ DIDS.

is not sufficient to postulate a sodium bicarbonate cotransport, and further characterization of the ion dependence (key predictions 1-4) of the transport is required. Furthermore, membrane potential changes due to $\mathrm{pH}_{\mathrm{i}}$ variations induced by altering electroneutral $\mathrm{Na}^{+}$$\mathrm{HCO}_{3}^{-}$cotransport or $\mathrm{Na}^{+}$-dependent $\mathrm{Cl}^{-}-\mathrm{HCO}_{3}^{-}$exchange should be considered. Another more complicated model that would lead to the same predictions is an electroneutral sodium-dependent chloride bicarbonate exchanger working in parallel with a chloride conductance. However, H7CM cells do not seem to possess a high chloride conductance because removal of extracellular chloride only led to a transient hyperpolarization, which was due to the liquid junction potential, followed by a very slow depolarization (data not shown). For H7CM cells and primary-cultured human ciliary muscle cells, we thus favor the model of an electrogenic $\mathrm{Na}^{+}$$\mathrm{HCO}_{3}^{-}$cotransport. This membrane transporter has already been shown to be present in various epithelial (2, $7,12,20,22,25,31,32)$ and glia cells (8) but has not yet been described for cells of muscular origin.

Removal of extracellular $\mathrm{HCO}_{3}^{-}$. Changing the extracellular solution from $46 \mathrm{HCO}_{3}^{-}$and $9 \% \mathrm{CO}_{2}$ to a HEPESbuffered standard solution (at a constant $\mathrm{pH}_{\mathrm{o}}$ ) resulted in rapid DIDS-sensitive membrane depolarization. This depolarization could be explained by an electrogenic $\mathrm{Na}^{+}$$\mathrm{HCO}_{3}^{-}$cotransport. However, this effect would also be expected for a simple bicarbonate or $\mathrm{H}^{+}$and $\mathrm{OH}^{-}$conductance because simultaneous removal of $\mathrm{HCO}_{3}^{-}-\mathrm{CO}_{2}$ will lead to a pronounced but transient intracellular alkalinization due to rapid decrease of $\mathrm{PCO}_{2} \cdot \mathrm{pH}_{\mathrm{i}}(5,10$, 16) and $\mathrm{pH}_{\mathrm{o}}(1,5,10,16,23,24)$ are known to influence potassium conductance. Intracellular and extracellular alkalinization usually increase the relative potassium conductance, thus leading to a membrane hyperpolarization $(5,10,16)$, and intracellular and extracellular acidification have the opposite effect $(1,5,10,16,23$, $24)$. Thus a $\mathrm{pH}$-sensitive potassium conductance is unlikely to contribute to the depolarizing effect of $\mathrm{HCO}_{3}^{-}$$\mathrm{CO}_{2}$ removal. However, variations of $\mathrm{pH}_{\mathrm{i}}$ are known to influence other $\mathrm{pH}$-regulating transport proteins (e.g., $\mathrm{Na}^{+}-\mathrm{H}^{+}$antiport), which could lead to changes in intra- cellular ion activities and ultimately influence the membrane potential. This explanation is unlikely for our experiments becuase $\mathrm{pH}_{\mathrm{i}}$ changes induced by removal of $\mathrm{HCO}_{3}^{-}-\mathrm{CO}_{2}$ are not abolished in the presence of DIDS, as is the case for variations in membrane voltage (data not shown).

Removal of extracellular $\mathrm{Na}^{+}$. On the basis of the Nernst equation, it could be inferred that removal of extracellular sodium will result in a hyperpolarization towards the sodium equilibrium potential. However, its removal from H7CM and primary-cultured human ciliary muscle cells led to a rapid membrane depolarization that cannot be explained by a simple sodium conductance. Besides electrogenic $\mathrm{Na}^{+}-\mathrm{HCO}_{3}^{-}$cotransport, there are other mechanisms that could theoretically mediate a membrane depolarization when extracellular sodium is removed: 1) high conductance for the replacing cation (NMDG); 2) decreased activity of the $\mathrm{Na}^{+}-\mathrm{K}^{+}$-adenosinetriphosphatase (ATPase) due to decreased intracellular sodium activity; 3 ) decreased $\mathrm{pH}$-sensitive potassium conductance due to intracellular acidification mediated by sodium-proton exchange; and 4) decreased $\mathrm{pH}$-sensitive potassium conductance due to intracellular acidification mediated by bicarbonate-dependent and DIDSsensitive transporters like sodium-dependent chloride bicarbonate exchange. This could theoretically also explain the bicarbonate dependence and the DIDS sensitivity of the membrane depolarization induced by removal of external sodium.

Point 1 is very unlikely because of the completely different structure and magnitude of NMDG compared with the sodium ion. Concerning point 2, it is also unlikely that the extreme depolarization induced by removal of extracellular sodium is completely mediated by inhibition of the $\mathrm{Na}^{+}-\mathrm{K}^{+}$-ATPase because, in a recent study (18), we showed that inhibition of $\mathrm{Na}^{+}-\mathrm{K}^{+}$-ATPase with ouabain only led to a rapid depolarization of $\mathrm{H} 7 \mathrm{CM}$ cells $(10.6 \pm 1.7 \mathrm{mV}, n=8)$, which we have interpreted to represent the direct contribution of $\mathrm{Na}^{+}-\mathrm{K}^{+}$-ATPase to the membrane potential. However, we cannot exclude that intracellular sodium depletion and subsequently decreasing $\mathrm{Na}^{+}-\mathrm{K}^{+}$-ATPase activity may contribute at 


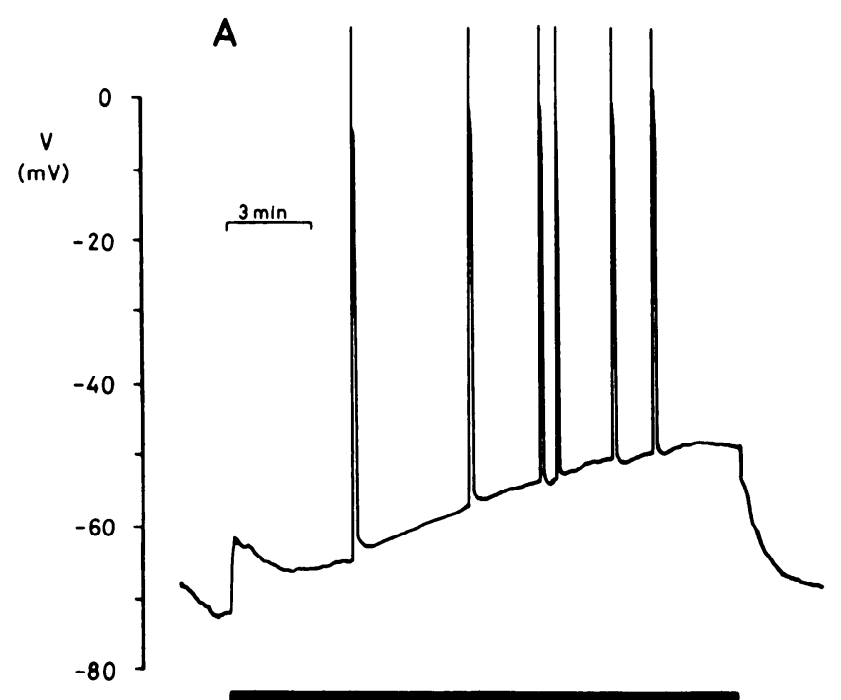

$\mathrm{BaCl}_{2} \quad 10 \mathrm{mmol} / \mathrm{l}$
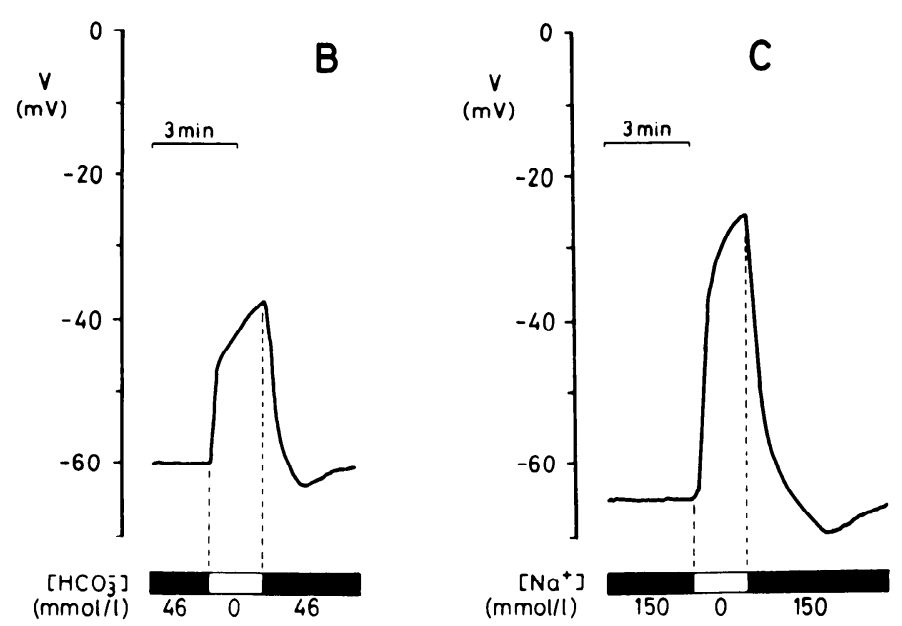

Fig. 7. $A$ : application of $10 \mathrm{mM} \mathrm{BaCl}$ to primary-cultured human ciliary muscle cells resulted in a membrane depolarization with superimposed action potentials. $B$ : changing from a high-bicarbonate (46 $\mathrm{mM} \mathrm{HCO}--9 \% \mathrm{CO}_{2}$ ) to a HEPES-buffered extracellular solution depolarized primary-cultured human ciliary muscle cells. $C$ : removal of extracellular sodium depolarized primary-cultured human ciliary muscle cells.

least partly to the depolarizing effect of sodium removal. Concerning points 3 and 4 , we have shown that the intracellular acidification induced by removal of extracellular sodium is not significantly different in the presence or absence of bicarbonate or in the presence of DIDS (see Table 2). Thus different $\mathrm{pH}_{\mathrm{i}}$ changes cannot be the reason for the different effects of sodium removal (see Figs. 2A, 3, and 4 and Table 1). The observation that DIDS had no effect on the acidification induced by sodium removal is unexpected. If a DIDS-sensitive $\mathrm{Na}^{+}$$\mathrm{HCO}_{3}^{-}$transporter is present in $\mathrm{H} 7 \mathrm{CM}$ cells, the acidification induced by sodium removal should be less in the presence of DIDS. However, application of DIDS per se acidified the cells $(0.25 \pm 0.02 \mathrm{pH} \mathrm{U} / 6 \mathrm{~min})$. Thus the total acidification induced by sodium removal in the presence of DIDS may be the sum of DIDS acidification and the acidification induced by reversal of $\mathrm{Na}^{+}-\mathrm{H}^{+}$ exchange. Considering both, the incomplete inhibition of the effect of sodium removal even if DIDS is applied for prolonged periods (sufficient to completely inhibit the effect of $\mathrm{HCO}_{3}^{-}$removal) and the remaining depolarization after sodium removal in the absence of bicarbonate, we cannot rule out the possibility that a component of the observed changes in membrane potential may reflect the involvement of additional transport mechanisms, such as a pH-sensitive potassium conductance or another still unknown process. In some of our experiments, we observed an initial hyperpolarization on removal of extracellular sodium. This hyperpolarization seems to be more pronounced when the resting potential is relatively low and when sodium is removed in the absence of $\mathrm{HCO}_{3}^{-}$or in the presence of DIDS. This is consistent with a simple sodium conductance that is difficult to observe when the resting potential is already high and when the depolarization induced by $\mathrm{Na}^{+}-\mathrm{HCO}_{3}^{-}$cotransport is not inhibited. An electrogenic sodium-calcium exchange mechanism could also induce a hyperpolarization when extracellular sodium is removed. However, the nature of the hyperpolarization remains to be clarified. When external sodium was removed in the absence of $\mathrm{CO}_{2}-\mathrm{HCO}_{3}^{-}$, we often observed a transient depolarization when sodium was readded. In a few experiments, this depolarization led to a superimposed action potential (Fig. 4). H7CM cells have already been shown to generate verapamil-sensitive action potentials (18), and thus they are probably mediated by voltage-operated calcium channels. In smooth muscle cells, action potentials occur when a large population of voltage-operated calcium channels are converted from the closed to the open state. This conversion cannot happen if most of the channels are inactivated at a low membrane potential. The inactivation of voltage-operated calcium channels may be an explanation for the difference in membrane voltage changes upon sodium restoration in the absence of $\mathrm{CO}_{2}$ $\mathrm{HCO}_{3}^{-}$[membrane potential $\left(\mathrm{V}_{\mathrm{m}}\right)=-35 \mathrm{mV}$ in Fig. 3, right, and $\mathrm{V}_{\mathrm{m}}=-70 \mathrm{mV}$ in Fig. 4].

Activation of $\mathrm{Na}^{+}-\mathrm{HCO}_{3}^{-}$cotransport by intracellular acidification. Variations in $\mathrm{pH}_{\mathrm{i}}$ are known to influence membrane voltage by different mechanisms. Possible mechanisms by which $\mathrm{pH}_{\mathrm{i}}$ could influence membrane voltage are as follows: 1) $\mathrm{pH}$ sensitive ion conductances, e.g., a $\mathrm{pH}$-sensitive potassium conductance; 2) conductivities for $\mathrm{H}^{+}, \mathrm{OH}^{-}$, and $\mathrm{HCO}_{3}^{-}$; and 3) electroneutral or electrogenic $\mathrm{pH}_{\mathrm{i}}$-regulating transporters leading to changes of intracellular ionic activities or directly influencing the membrane voltage. Although we could not completely rule out the contribution of other additional transport mechanisms, our data strongly suggest that $\mathrm{Na}^{+}-\mathrm{HCO}_{3}^{-}$cotransport is activated by intracellular acidification, thus leading to the observed hyperpolarization. A pH-sensitive potassium conductance is not consistent with the observed voltage changes, since intracellular and extracellular acidification is considered to cause depolarization by decreasing the potassium conductance, leading to a depolarization $(1,5,10,16,23,24)$. Thus, although we cannot exclude the presence of a $\mathrm{pH}$-sensitive potassium conductance and its possible contribution to the depolarization after sodium removal, the effect of intracellular acidification on the potassium conductance 
seems to be small, and another hyperpolarizing mechanism (electrogenic $\mathrm{Na}^{+}-\mathrm{HCO}_{3}^{-}$cotransport) must be operative when the cells were acidified. We can exclude that fluxes of $\mathrm{H}^{+}, \mathrm{OH}^{-}$, or $\mathrm{NH}_{4}^{+}$ions contribute to the hyperpolarization because these fluxes would also occur in the absence of $\mathrm{HCO}_{3}^{-}-\mathrm{CO}_{2}$ or extracellular sodium. Although the $\mathrm{pH}_{\mathrm{i}}$ slopes after $\mathrm{NH}_{4} \mathrm{Cl}$ removal are not markedly different (Fig. 5), the variations in membrane voltage differ completely depending on whether $\mathrm{HCO}_{3}^{-}$ $\mathrm{CO}_{2}$ is present or absent (shown in Figs. 5 and 6), suggesting the involvement of bicarbonate-dependent mechanisms in the hyperpolarization. Though a DIDSsensitive $\mathrm{HCO}_{3}^{-}$conductance is not excluded, $\mathrm{Na}^{+}$$\mathrm{HCO}_{3}^{-}$cotransport is a more likely mediator of the hyperpolarization because not only the bicarbonate dependence and DIDS sensitivity but also the sodium dependence can be explained by such a transport. The observed depolarization when $\mathrm{NH}_{4} \mathrm{Cl}$ was added could to some extent be explained by an electrogenic $\mathrm{Na}^{+}-\mathrm{HCO}_{3}^{-}$ cotransport. We suggest that the transporter plays only a minor role in mediating this depolarization, which takes a slow time course, while the alkalinization is rapid.

Transport direction and stoichiometry. The $\mathrm{Na}^{+}-$ $\mathrm{HCO}_{3}^{-}$cotransport in bicarbonate-absorbing epithelia is considered to be located at the basolateral membrane mediating basolateral bicarbonate fluxes $(2,9,22,25)$. In these cells, bicarbonate is transported across the cell membrane from inside to outside under steady-state conditions. The stoichiometry is supposed to be $3: 1$ rather than 2:1 $(25,32)$. In cultured renal $\mathrm{BSC} 1$ cells, this transporter has been shown to carry a net negative charge inside the cell, contributing to some extent to the resting membrane potential (15). In our experiments, application of DIDS under steady-state conditions with extracellular $\left[\mathrm{Na}^{+}\right]=151 \mathrm{mM}$, extracellular $\left[\mathrm{HCO}_{3}\right]=$ $28 \mathrm{mM}$, and intracellular $\left[\mathrm{HCO}_{3}\right]=16 \mathrm{mM}$ (calculated from $\mathrm{pH}_{\mathrm{i}}=7.21 \pm 0.03, n=5$ and $\mathrm{PCO}_{2}=5 \%$ ) resulted in a depolarization, indicating an inward transport of negative charges by $\mathrm{Na}^{+}-\mathrm{HCO}_{3}^{-}$cotransport. Calculation of the equilibrium potential for this transport system, assuming a 2:1 stoichiometry, yields -102 or $-73 \mathrm{mV}$ (intracellular $\left[\mathrm{Na}^{+}\right]$was assumed 10 or $30 \mathrm{mM}$, respectively, because measurement of intracellular $\left[\mathrm{Na}^{+}\right]$using the sodium-sensitive dye SBFI revealed intracellular $\left[\mathrm{Na}^{+}\right]$values between 10 and $30 \mathrm{mM}$ ) and $-58 \mathrm{mV}$ or $-44 \mathrm{mV}$ for a $3: 1$ stoichiometry. Although an inward transport under steady-state conditions can be better explained assuming a 2:1 stoichiometry, we cannot finally exclude a $3: 1$ cotransport.

Electrogenic $\mathrm{Na}^{+}-\mathrm{HCO}_{3}^{-}$cotransport in the eye. An electrogenic $\mathrm{Na}^{+}-\mathrm{HCO}_{3}^{-}$cotransport system has been demonstrated in different cells from the eye, namely bovine cornea endothelial cells (12), frog retinal pigment epithelium (20), toad lens epithelium (31), and rabbit ciliary epithelium (4). Recently, we showed that an electrogenic $\mathrm{Na}^{+}-\mathrm{HCO}_{3}^{-}$cotransport is absent in bovine trabecular meshwork cells (6). Thus this transporter may serve as a tool to differentiate between ciliary muscle cells and cells derived from trabecular meshwork, which has likewise proven to be contractile (21).
In summary, we demonstrate membrane properties consistent with electrogenic $\mathrm{Na}^{+}-\mathrm{HCO}_{3}^{-}$cotransport in human ciliary muscle cells. This transport system may contribute to the regulation of membrane voltage under steady-state conditions and to the regulation of $\mathrm{pH}_{\mathrm{i}}$ after intracellular acidification. It could also be used as a tool to differentiate between cultured cells of the eye.

The excellent technical assistance of Marianne Koch and Astrid Krolik is greatfully acknowledged.

This work was supported by the Dentsche Forschungsgemeinschaft Grant DFG Wi 328/11.

Address for reprint requests: F. Stahl, Institut für Klinische Physiologie, Universitätsklinikum Steglitz, Freie Universität Berlin, Hindenburgdamm 30, 1000 Berlin 45, FRG.

Received 7 March 1991; accepted in final form 19 August 1991.

\section{REFERENCES}

1. Biagi, B. A., and M. Sohtell. pH sensitivity of the basolateral membrane of the rabbit proximal tubule. Am. J. Physiol. 250 (Renal Fluid Electrolyte Physiol. 19): F261-F266, 1986.

2. Boron, W. F., and E. L. Boulpaep. Intracellular $\mathrm{pH}$ regulation in the renal proximal tubule of the salamander. Basolateral $\mathrm{HCO}_{3}^{-}$transport. J. Gen. Physiol. 81: 53-94, 1983.

3. Boron, W. F., and $\mathbf{P}$. de Weer. Intracellular $\mathrm{pH}$ transients in squid giant axons caused by $\mathrm{CO}_{2}, \mathrm{NH}_{3}$, and metabolic inhibitors. J. Gen. Physiol. 67: 91-112, 1976.

4. Chu, T. C., and K. Green. Bicarbonate and DIDS effects on intracellular potential difference in rabbit ciliary epithelium. Curr. Eye Res. 9: 233-239, 1990.

5. Cook, D. L., M. Ikeuchi, and W. Y. Fujimoto. Lowering of $\mathrm{pH}_{\mathrm{i}}$ inhibits $\mathrm{Ca}^{2+}$-activated $\mathrm{K}^{+}$channels in pancreatic B-cells. Nature Lond. 311: 269-271, 1984.

6. Coroneo, M. T., C. Korbmacher, B. Stiemer, C. Flügel, E. Lütjen-Drecoll, and M. Wiederholt. Electrical and morphological evidence for heterogeneous populations of cultured bovine trabecular meshwork cells. Exp. Eye Res. 52: 375-388, 1991.

7. Curci, S., L. Debellis, and E. Frömter. Evidence for rheogenic sodium bicarbonate cotransport in the basolateral membrane of oxyntic cells of frog gastric fundus. Pfluegers Arch. 408: 497-504, 1987.

8. Deitmer, J. W., and W.-R. Schlue. An inwardly directed electrogenic sodium-bicarbonate co-transport in leech glial cells. $J$. Physiol. Lond. 411: 178-194, 1989.

9. Grassl, S. M., and P. S. Aronson. $\mathrm{Na}^{+}-\mathrm{HCO}_{3}^{-}$co-transport in basolateral membrane vesicles isolated from rabbit renal cortex. $J$. Biol. Chem. 261: 8778-8783, 1986.

10. Helbig, H., C. Korbmacher, and M. Wiederholt. $\mathrm{K}^{+}$conductance and electrogenic $\mathrm{Na}^{+} / \mathrm{K}^{+}$transport of cultured bovine pigmented ciliary epithelium. J. Membr. Biol. 99: 173-186, 1987.

11. Ishikawa, T. Fine structure of the human ciliary muscle. Invest. Ophthalmol. 1: 587-608, 1962.

12. Jentsch, T. J., S. K. Keller, M. Koch, and M. Wiederholt. Evidence for coupled transport of bicarbonate and sodium in cultured bovine corneal endothelial cells. J. Membr. Biol. 81: 189 204, 1984.

13. Jentsch, T. J., M. Koch, H. Bleckmann, and M. Wiederholt. Effect of bicarbonate, $\mathrm{pH}$, methazolamide, and stilbenes on the intracellular potential of cultured bovine corneal endothelial cells. J. Membr. Biol. 78: 103-117, 1984.

14. Jentsch, T. J., I. Janicke, D. Sorgenfrei, S. K. Keller, and M. Wiederholt. The regulation of intracellular $\mathrm{pH}$ in monkey kidney epithelial cells (BSC-1). J. Biol. Chem. 261: 12120-12127, 1986.

15. Jentsch, T. J., H. Matthes, S. K. Keller, and M. Wiederholt. Electrical properties of sodium bicarbonate symport in kidney epithelial cells (BSC-1). Am. J. Physiol. 251 (Renal Fluid Electrolyte Physiol. 20): F954 F968, 1986.

16. Keller, S. K., T. J. Jentsch, M. Koch, and M. Wiederholt. Interactions of $\mathrm{pH}$ and $\mathrm{K}^{+}$conductance in cultured bovine retinal pigment epithelial cells. Am. J. Physiol. 250 (Cell Physiol. 19): C124-C137, 1986. 
17. Kikeri, D., S. Azar, A. Sun, M. I. Zeidel, and S. C. Hebert. $\mathrm{Na}^{+}-\mathrm{H}^{+}$antiporter and $\mathrm{Na}^{+}-\left(\mathrm{HCO}_{3}^{-}\right)_{n}$ symporter regulate intracellular $\mathrm{pH}$ in mouse medullary thick limbs of Henle. Am. J. Physiol. 258 (Renal Fluid Electrolyte Physiol. 27): F445-F456, 1990.

18. Korbmacher, C., H. Helbig, M. T. Coroneo, C. A. EricksonLamy, B. Stiemer, E. Tamm, E. Lütjen-Drecoll, and $M$. Wiederholt. Membrane voltage recordings in a cell line derived from human ciliary muscle. Invest. Ophthalmol. Visual Sci. 31: 2420-2430, 1990.

19. Korbmacher, C., H. Helbig, H. Haller, K. A. EricksonLamy, and M. Wiederholt. Endothelin depolarizes membrane voltage and increases intracellular calcium concentration in human ciliary muscle cells. Biochem. Biophys. Res. Commun. 164: 1031$1039,1989$.

20. LaCour, M. Rheogenic sodium-bicarbonate cotransport across the retinal membrane of the frog retinal pigment epithelium. J. Physiol. Lond. 419: 539-553, 1989.

21. Lepple-Wienhues, A., F. Stahl, and M. Wiederholt. Differential smooth-muscle like contractile properties of trabecular meshwork and ciliary muscle. Exp. Eye Res. 53: 33-38, 1991.

22. Lopes, A. G., A. W. Siebens, G. Giebisch, and W. F. Boron. Electrogenic $\mathrm{Na} / \mathrm{HCO}_{3}$ cotransport across basolateral membrane of isolated perfused Necturus proximal tubule. Am. J. Physiol. 253 (Renal Fluid Electrolyte Physiol. 22): F340-F350, 1987.

23. Paulmichl, M., G. Gstraunthaler, and F. Lang. Electrical properties of Madin-Darby canine kidney cells. Effects of extracellular potassium and bicarbonate. Pfluegers Arch. 405: 102-107, 1985.

24. Reinach, P. S., C. Thurman, and G. Klemperer. Basolateral membrane $\mathrm{K}$ permselectivity and regulation in bullfrog cornea epithelium. J. Membr. Biol. 99: 205-213, 1987.

25. Sasaki, S., T. Shiigai, N. Yoshiyama, and J. Takeuchi. Mechanism of bicarbonate exit across basolateral membrane of rabbit proximal straight tubule. Am. J. Physiol. 252 (Renal Fluid Electrolyte Physiol. 21): F11-F18, 1987.

26. Stahl, F., A. Lepple-Wienhues, M. Kuppinger, U. Schneider, and M. Wiederholt. Measurements of intracellular calcium and contractility in human ciliary muscle. Pfluegers Arch. 418: 531537,1991

27. Tamm, E., C. Flügel, A. Baur, and E. Lütjen-Drecoll. Cell cultures of human ciliary muscle: growth, ultrastructural and immunocytochemical characteristics. Exp. Eye Res. 53: 375-387, 1991.

28. Townsley, M. C., and T. E. Machen. Na-HCO $\mathrm{H}_{3}$ cotransport in rabbit parietal cells. Am. J. Physiol. 257 (Gastrointest. Liver Physiol. 20): G350-G356, 1989.

29. Van der Zypen, E. Licht und elektronenmikroskopische Untersuchungen über den Bau und die Innervation des Ziliarmuskels bei Mensch und Affe (Cercopithecus aethiops). Graefe's Arch. Clin. Exp. Ophthalmol. 174: 143-168, 1967.

30. Wenzl, E., M. D. Sjaastad, W. H. Weintraub, and T. E. Machen. Intracellular pH regulation in IEC-6 cells, a cryptlike intestinal cell line. Am. J. Physiol. 257 (Gastrointest. Liver Physiol. 20): G732-G740, 1989.

31. Wolosin, J. M., J. A. Lawrence, and O. A. Candia. $\mathrm{HCO}_{3}^{-}$ transport in the toad lens epithelium is mediated by an electronegative $\mathrm{Na}^{+}$-dependent symport. Am. J. Physiol. 258 (Cell Physiol. 27): C855-C861, 1990.

32. Yoshitomi, K., B.-C. Burckhardt, and E. Frömter. Rheogenic sodium-bicarbonate cotransport in the peritubular cell membrane of rat renal proximal tubule. Pfluegers Arch. 405: 360-366, 1985.

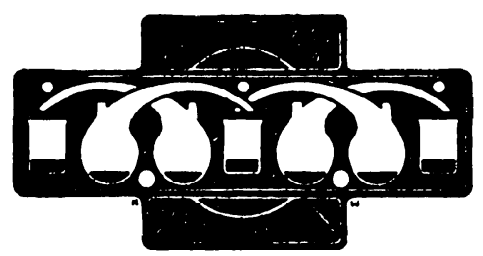

